\title{
Arterial tortuosity syndrome
}

\author{
Erfan Mehrabi, ${ }^{1}$ Kamran Khan, ${ }^{2}$ Shahab A Malik ${ }^{1}$
}

'Department of Pediatrics, MedStar Harbor Hospital, Baltimore, Maryland, USA ${ }^{2}$ Department of General Surgery, Sinai Hospital of Baltimore, Baltimore, Maryland, USA

\section{Correspondence to} Kamran Khan, kamkmd92@ gmail.com
Accepted 5 September 2016

\section{DESCRIPTION}

An infant exhibited weight faltering and failure to thrive after birth. She was born full term via an uncomplicated vaginal delivery to healthy, nonconsanguineous parents. The mother received prenatal care and standard screening tests were reportedly normal throughout pregnancy. There was no family history of disease. Birth weight was 6 pounds, head circumference was $36 \mathrm{~cm}$ and length was $51 \mathrm{~cm}$. On examination, there was a significant blood pressure discrepancy of $90-95 \mathrm{~mm} \mathrm{Hg}$ systolic in the upper extremities and $60 \mathrm{~mm} \mathrm{Hg}$ systolic in the lower extremities. The patient was noted to have micrognathia, prune skin and down slanting palpebral fissures. Laboratory analysis was within normal limits. CT angiography with 3D reconstruction revealed tortuosity throughout the arterial tree (figure 1). There was a right-sided kink of the descending aorta (figure 2) and mild stenosis of the distal edge of the aortic arch (at and before the ligamentum arteriosum), proximal descending aorta, right and left pulmonary arteries. Electrophoresis and DNA sequencing subsequently confirmed the diagnosis of arterial tortuosity syndrome (ATS). The patient underwent multiple percutaneous balloon dilatations and stent placement for vessel stenosis. She underwent correctional surgery, including multiple patch augmentation, to correct the anatomic abnormalities. She is currently

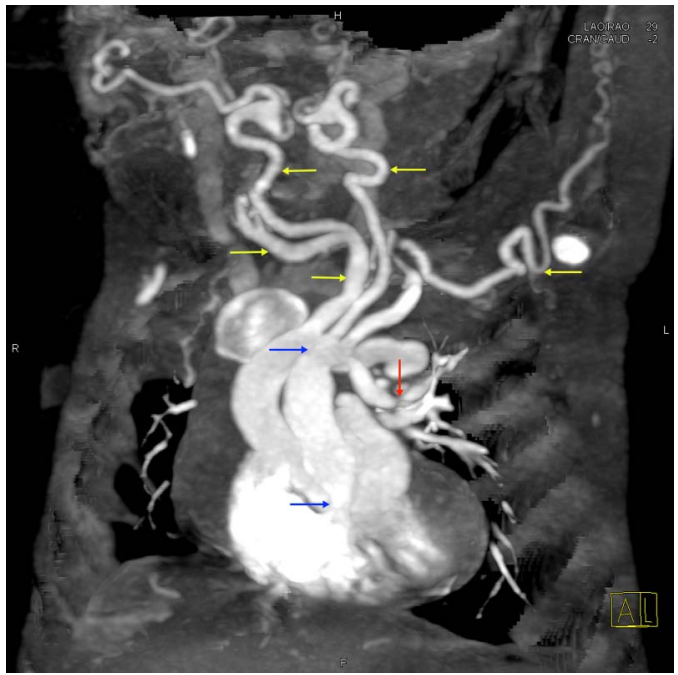

CrossMark

To cite: Mehrabi E, Khan $\mathrm{K}_{\text {, }}$ Malik SA. BMJ Case Rep Published online: [please include Day Month Year] doi:10.1136/bcr-2016217029 asymptomatic and is being monitored for disease progression.

ATS is a rare autosomal recessive connective tissue disease characterised by elongation and tortuosity of the large-sized and medium-sized arteries. This was first described in 1967 by Ertugrul. ${ }^{1}$ The aetiology of the disease involves alterations in the vascular elastic fibres of the tunica media, leading to aneurysms, dissections and stenosis of these vessels. $^{2}$ A loss-of-function mutation of the SLC2A10 gene leads to a decreased transcription of decorin, the inhibitor of the transforming growth factor beta (TGFB) signalling pathway. ${ }^{3}$ This ultimately leads to disinhibition of the TGFB signalling pathway and inhibition of proper extracellular matrix formation, causing tortuosity of arterial vessels. $^{3}$

Patients present with connective tissue manifestations, including characteristic facial features, hernias, cutix laxa and hyper-extensible skin. Characteristic facial features include micrognathia, elongated face, high palate, beaked nose and down slanting palpebral fissures. ${ }^{3}$ Owing to these manifestations, ATS is often misdiagnosed as other connective tissue diseases, including Loeys Dietz syndrome, Marfan syndrome and Ehlers-Danlos syndrome.

Neonates and infants presenting with features of pulmonary artery stenosis, with or without characteristic craniofacial features, should be screened for ATS. Cardiac catheterisation and CT angiography are useful diagnostic considerations.

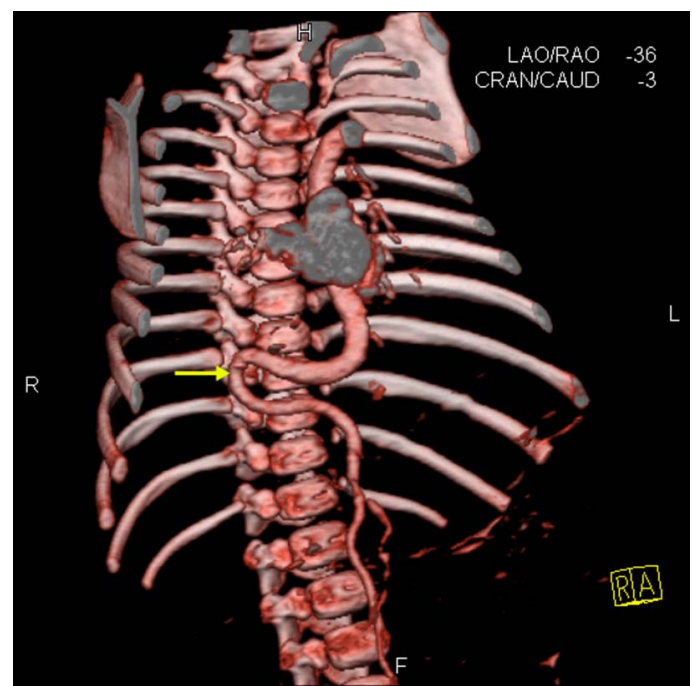

Figure 2 CT 3D reconstruction reveals a right-sided kink of the descending aorta as it approaches the diaphragm (yellow arrow). 


\section{Learning points}

A loss-of-function mutation of the $S L C 2 A 10$ gene leads to a decreased transcription of decorin, the inhibitor of the TGFB signalling pathway. ${ }^{3}$ This ultimately leads to disinhibition of the TGFB signalling pathway and inhibition of proper extracellular matrix formation, causing tortuosity of arterial vessels. $^{3}$

- A review of 71 cases of ATS described in the literature revealed that consanguinity was present $46 \%$ of the time, further corroborating the autosomal recessive inheritance pattern. Additionally, $58 \%$ of the diagnosed cases were male.

- Neonates and infants presenting with features of pulmonary artery stenosis, with or without characteristic craniofacial features, should be screened for ATS. Cardiac catheterisation and CT angiography are useful diagnostic considerations.
Contributors EM, KK and SAM were equally involved in planning and writing the manuscript. All authors contributed equally.

Competing interests None declared.

Patient consent Obtained.

Provenance and peer review Not commissioned; externally peer reviewed.

\section{REFERENCES}

1 Ertugrul A. Diffuse tortuosity and lengthening of the arteries. Circulation 1967:36:400-7.

2 Marwah A, Shah S, Suresh PV, et al. Arterial tortuosity syndrome: a rare entity. Ann Pediatr Cardiol 2008;1:62-4.

3 Callewaert BL, Willaert A, Kerstjens-Frederikse WS, et al. Arterial tortuosity syndrome: clinical and molecular findings in 12 newly identified families. Hum Mutat 2008;29:150-8.

Copyright 2016 BMJ Publishing Group. All rights reserved. For permission to reuse any of this content visit http://group.bmj.com/group/rights-licensing/permissions.

BMJ Case Report Fellows may re-use this article for personal use and teaching without any further permission.

Become a Fellow of BMJ Case Reports today and you can:

- Submit as many cases as you like

- Enjoy fast sympathetic peer review and rapid publication of accepted articles

- Access all the published articles

- Re-use any of the published material for personal use and teaching without further permission

For information on Institutional Fellowships contact consortiasales@bmjgroup.com

Visit casereports.bmj.com for more articles like this and to become a Fellow 